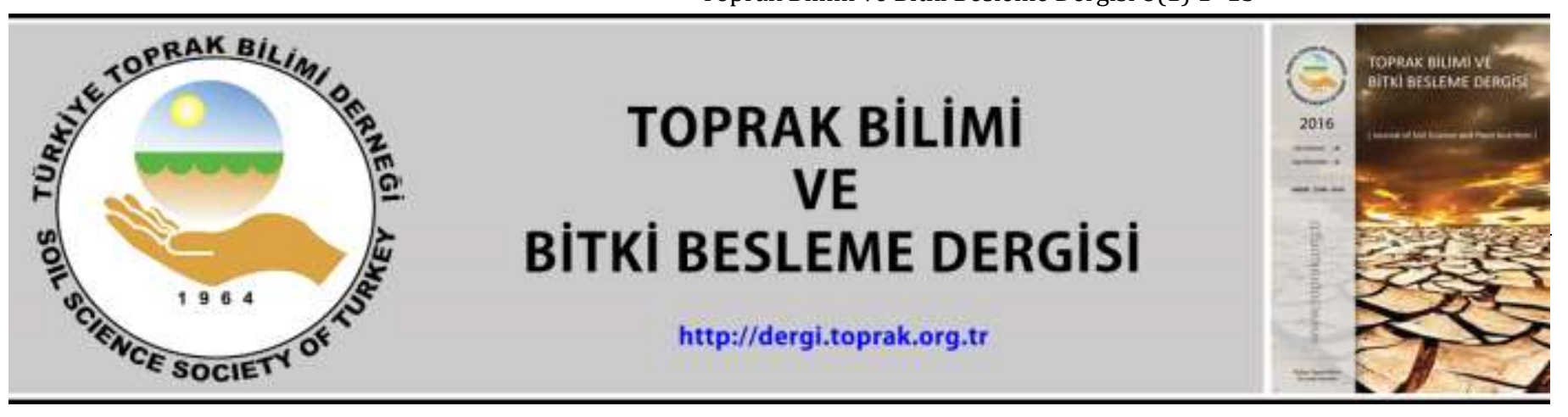

\title{
Piroliz sıcaklığının biyoçarların bazı fiziksel ve kimyasal özellikleri üzerine etkileri
}

\section{Burhan Akkurt 1,*, ○Hikmet Günal 2, ○Halil Erdem 2, $\odot$ Elif Günal ${ }^{2}$}

\author{
1 Orta Karadeniz Geçit Kuşağı Tarımsal Araştırma Enstitüsü Müdürlüğü, Taşlıçiftlik, Tokat \\ ${ }^{2}$ Gaziosmanpașa Üniversitesi, Ziraat Fakültesi, Toprak Bilimi ve Bitki Besleme Bölümü, Tokat
}

\begin{abstract}
Özet
Bu çalışmada, yedi farklı hammaddeden 3 farklı sıcaklıkta (300, 400 ve $\left.600{ }^{\circ} \mathrm{C}\right)$ piroliz ile elde edilen biyoçarların çeşitli fiziksel ve kimyasal özellikleri belirlenmiș ve bitki yetiștiriciliği açısından karșılaştırılmaları yapılmıștır. Çalışmada, bölgede kolaylıkla temin edilebilen domates atıkları (sap, gövde ve yaprakları), kavak talaşı, buğday samanı, mısır koçanı, fasulye atıkları, çeltik kavuzu ve büyükbaş hayvan gübresi hammadde olarak kullanılmıştır. Üretilen biyoçarların, verimi, spesifik yüzey alanları (SYA), tarla kapasitesi (TK), solma noktası (SN) ve yarayıșlı su içerikleri (YSi), pH, elektriksel iletkenlik (EC), katyon değișim kapasitesi (KDK), toplam karbon $(\mathrm{C})$ ve azot $(\mathrm{N})$, kalsiyum $(\mathrm{Ca})$, magnezyum $(\mathrm{Mg})$, potasyum $(\mathrm{K})$, çinko $(\mathrm{Zn})$, demir $(\mathrm{Fe})$, bakır $(\mathrm{Cu})$ ve mangan $(\mathrm{Mn})$ konsantrasyonları belirlenmiștir. Piroliz sıcaklığının $300{ }^{\circ} C^{\prime}$ den $600{ }^{\circ} C^{\prime}$ ye çıkarılması tüm biyoçar çeșitlerinde üretilen biyoçar miktarında ve SYA'nında azalmaya neden olmuștur. SYA'daki en belirgin azalma $300{ }^{\circ} \mathrm{C}^{\prime} \mathrm{de} 758.3 \mathrm{~m}^{2} \mathrm{~g}^{-1}$ olan yüzey alanı $600{ }^{\circ} C^{\prime}$ de $250.8 \mathrm{~m}^{2} \mathrm{~g}^{-1}$ 'e düșen kavak talaşı olmuştur. Piroliz sıcaklığının artışı istatistiksel olarak önemli olmamakla birlikte TK, SN ve YSİ’nde artışa neden olmuştur. Nem içeriklerinde olduğu gibi, piroliz sıcaklığının artışı tüm biyoçar çeşitlerinin pH değerlerinin istatistiksel olarak önemli düzeyde artmasına neden olmuştur. Bununla birlikte EC değerleri sıcaklık artışından önemli düzeyde etkilenmemiștir. Biyoçar çeșidine bağlı olarak önemli ölçüde değișkenlik gösteren KDK değerleri $300{ }^{\circ} \mathrm{C}^{\prime} l i k$ piroliz sıcaklığında $33.47 \mathrm{cmolc} \mathrm{kg}^{-1}$ 'den $88.16 \mathrm{cmolc} \mathrm{kg}{ }^{-1}$ 'a, $400{ }^{\circ}{ }^{\circ}{ }^{\prime}$ de $41.87 \mathrm{cmolc} \mathrm{kg}{ }^{-1}$ 'den $78.68 \mathrm{cmolc} \mathrm{kg}{ }^{-1}$ 'e ve $600{ }^{\circ} \mathrm{C}^{\prime}$ de ise $23.27 \mathrm{cmolc} \mathrm{kg}^{-1}{ }^{\prime} \mathrm{den}$ 68.03 cmolc kg-1'e kadar değişkenlik göstermiștir. Sıcaklık artışı ile büyükbaş hayvan gübresinden üretilen biyoçarın toplam karbon içeriği azalırken fasulye biyoçarında bir değişim olmamıș ancak diğer beș biyoçarın karbon içeriği artmıștır. Sıcaklık artışı özellikle $400{ }^{\circ} C^{\prime}$ den sonra toplam N içeriğinin önemli düzeyde azalmasına yol açmıştır. Tüm biyoçar çeşitlerinde piroliz sıcaklığının 300 o C'den 600 o C'ye çıkarılması P ve K içeriklerinin artıșına yol açmıștır. Sonuçlar, biyoçarların verimlerinin ve özelliklerinin piroliz sıcaklığına bağlı olarak önemli oranda değiștiğini göstermiştir. Yüksek sıcaklıkta $\left(600^{\circ} \mathrm{C}\right)$ üretilen biyoçarların çoğunlukla daha yüksek $\mathrm{pH}$ ve $\mathrm{EC}$ değerlerine ve mikro ( $\mathrm{Cu}, \mathrm{Fe}, \mathrm{Zn}$ ve $\mathrm{Mn}$ ) ve makro ( $\mathrm{P}, \mathrm{K}, \mathrm{Ca}$ ve $\mathrm{Mg}$ ) element konsantrasyonlarına sahip olduğu belirlenmiștir.
\end{abstract}

Anahtar Kelimeler: Biyoçar, sıcaklık, piroliz, tarımsal atık, karbon.

\section{Effects of pyrolysis temperature on some of physical and chemical characteristics of biochars}

\begin{abstract}
In this study, various physical and chemical properties of biochars produced by slow pyrolysis at 3 different temperatures (300, 400 and $600{ }^{\circ} \mathrm{C}$ ) from seven different feedstocks were determined and compared in terms of agricultural production. Tomato wastes (stem, roots and leaves), poplar sawdust, wheat straw, corncob, bean plant wastes, rice husk and cattle manure were used as raw materials. Yield, specific surface area (SSA), field capacity (FC), wilting point (WP) and available water contents (AWC), pH, electrical conductivity (EC), cation exchange capacity (CEC), total carbon (TC) and nitrogen (TN), calcium (Ca), magnesium (Mg) potassium $(\mathrm{K})$, zinc $(\mathrm{Zn})$, iron $(\mathrm{Fe})$, copper $(\mathrm{Cu})$ and manganese $(\mathrm{Mn})$ concentrations of biochars produced were determined. Increasing the pyrolysis temperature from $300^{\circ} \mathrm{C}$ to $600{ }^{\circ} \mathrm{C}$ resulted in a decrease in yield and SSA of all biochar types. The most significant decrease in SSA was observed in sawdust in which the surface area was reduced from $758.3 \mathrm{~m}^{2} \mathrm{~g}^{-1}$ (300 $\left.{ }^{\circ} \mathrm{C}\right)$ to $250.8 \mathrm{~m}^{2}$ $\mathrm{g}^{-1}(600 \stackrel{\circ}{\circ})$. The increase in pyrolysis temperature caused a non-significant increase in FC, WP and AWC. The pH values of all biochar types significantly increase with the increase in the pyrolysis temperature. However, EC values were not significantly affected by increase in temperature. The CEC values significantly varied depending on the biochar types. The CEC value at $300{ }^{\circ} \mathrm{C}$ was between 33.47 and $88.16 \mathrm{cmolc} \mathrm{kg}^{-1}$, while it was between 41.87 and $78.68 \mathrm{cmolc} \mathrm{kg}^{-1} \mathrm{at}_{400}{ }^{\circ} \mathrm{C}$, and between 23.27 and 68.03 $\mathrm{cmolc} \mathrm{kg}^{-1}$ at $600{ }^{\circ} \mathrm{C}$. The TC content of the biochar produced from cattle manure decreased with the increase in temperature, no change was observed in the bean biochar, but the TC content of the other five biochars increased. The increase in temperature led to a significant decrease in the TN content especially after $400 \stackrel{\circ}{\circ}$. Increasing the pyrolysis temperature from 300 to $600 \stackrel{\circ}{\circ} \mathrm{C}$ in all biochar types led to an increase in $\mathrm{P}$ and $\mathrm{K}$ contents. The results indicated that the yields and properties of biochars strongly depend
\end{abstract}

\section{* Sorumlu yazar:}

Tel. : 03562521250

E-posta : b.akkurt-05@hotmail.com
Gelis Tarihi

Kabul Tarihi
30 Ekim 2019

18 Mayıs 2020
e-ISSN

DOI
2146-8141

10.33409/tbbbd.756797 
on the pyrolysis temperature. The biochars with high $\mathrm{pH}$ and $\mathrm{EC}$ values and micro $(\mathrm{Cu}, \mathrm{Fe}, \mathrm{Zn}$ and $\mathrm{Mn})$ and macro $(\mathrm{P}, \mathrm{K}, \mathrm{Ca}$ and $\mathrm{Mg})$ contents were produced at high pyrolysis temperature (600 $\left.{ }^{\circ} \mathrm{C}\right)$.

Keywords: Biochar, temperature, pyrolysis, agricultural waste, carbon.

(C) 2020 Türkiye Toprak Bilimi Derneği. Her Hakkı Saklıdır

\section{Giriş}

Biyokütlenin çok az oksijenin bulunduğu veya hiç olmadığı kapalı bir ortamda ssıtılması ile elde edilen karbon bakımından zengin olan materyallere biyoçar adı verilmektedir. Daha teknik anlamda, kısıtlı miktarda oksijenin olduğu ve göreceli olarak düșük sıcaklıklarda $\left(<700^{\circ} \mathrm{C}\right)$ organik materyallerin sıcaklıkla değişimi/pirolizi ile üretilen materyal biyoçar olarak adlandırılmaktadır (Lehmann ve Joseph 2009). Tarımsal atıklar, ormancılık atıkları ve arıtma çamuru gibi pek çok tür biyokütle biyoçar üretmek için kullanılabilmektedir (Xu ve ark., 2019; Banik ve ark., 2018; Li ve ark., 2017). Orta düzeyde yüksek sıcaklık altında kapalı bir ortamda biyokütle içerisindeki karbonhidratların yapısı karbonca daha zengin olan katılara dönüşmektedir.

Biyoçar adı verilen bu değerli ürün toprak kalitesinin iyileștirilmesi, kirliliğin giderilmesi başta olmak üzere, karbon tutumu gibi konularından dolayı, biyoçarın toprağa uygulanması ile ilgili araştırmalar önemli miktarda artmıştır (Woolf ve ark., 2010; Sohi, 2012; Sizmur ve ark., 2016). Biyoçar üretimi, özellikle biyolojik atıkların bol miktarda üretildiği ülkemizde, toprak verimliliği ile ilgili sorunların sürdürülebilir bir şekilde düzeltilmesine yardımcı olacak önemli bir katkı maddesi olarak düșünülebilir (Günal, 2018). Biyoçarın toprak kalitesinin korunması ve iyileștirilmesinde, su tutma kapasitesini ve katyon değișim kapasitesini optimize etmesinin yanı sıra toprağın erozyona duyarlılığını azaltması da önemlidir (Joseph ve ark., 2010). Ayrıca, biyoçar, azot (N), karbon (C) ve fosfor (P) gibi temel besin elementlerinin miktarını artırarak ve ağır metallerin biyo yarayışlılığını azaltarak da toprağın kalitesinin sürdürülebilirliğine katkı yapmaktadır (Zhang ve ark., 2016; Sarfraz ve ark., 2017).

Biyoçarların kullanılması, kirleticilerin tutulması ve daha birçok alanda aktif karbon kullanımına kıyasla nispeten düşük maliyetlidir (Tarpeh ve ark., 2017). Yüksek miktarda karbon içerdiğinden dolayı kömür gibi materyallerden çok daha yüksek enerji düzeyine sahiptir. Piroliz işlemi esnasında oluşan çok sayıdaki mikro gözeneklerden dolayı büyük miktarda yüzey alanına da sahip olabilmektedir. Mikro gözeneklerinin yüksek olması kirleticilerin filtre edilmesi ve adsorpsiyonunda kullanılabilmesini mümkün kılmaktadır (Lee ve ark., 2013). Üretim koşullarına bağlı olarak büyük değişkenlik gösteren biyoçarın özellikleri biyoçarın kullanım etkinliğini önemli ölçüde değiștirebilmektedir. Farklı biyoçarların potansiyel adsorpsiyon kapasiteleri, biyoçar üretiminde kullanılan hammaddenin spesifik özelliklerine bağlı olarak da büyük oranda değișkenlik göstermektedir (Yin ve ark., 2018).

Biyoçar ayrışmaya karşı dayanıklılı̆̆ının yüksek olması, alkali doğası, yüksek besin içeriği, gözenekli yapı, bitkilere besin sağlama yeteneği ve bitkilerin azot kullanımının verimliliğini artırmaya yardımcı olması gibi spesifik özellikleri nedeniyle toprak katkı maddesi olarak kullanılabilirliği araștırılmaya devam etmektedir (Kammann ve ark., 2011). Biyoçarı özel kılan bu özellikler, pirolizin sıcaklığının değiștirilmesi ile farklılaştırılabilir (Wu ve ark., 2012). Biyoçarın pH'sı, karbon ve bazik fonksiyonel gruplarının miktarı piroliz sıcaklığındaki artışla değiștirilebilir, genel olarak üretilen biyoçarın verimi ve özellikle de asidik fonksiyonel grupların miktarı sıcaklık artışı ile azaldığı bildirilmiştir (Sun ve ark., 2017).

Organik karbon açısından oldukça zengin olan biyoçarın aksine, biyokütlenin bir oksijenli ortamda yakılması ile organik materyal çoğunlukla kalsiyum, magnezyum ve inorganik karbonatlardan oluşan bir kül halini alır. Oldukça farklı materyallerden farklı koşullar altında biyoçar üretildiğinden dolayı kimyasal olarak biyoçarın tanımının yapılması oldukça güçtür. Biyoçarın genel olarak tanımlanabilen ortak özelliği oksijen ve hidrojen olmadan altı karbon atomunun oluşturmuş olduğu aromatik yapısındaki yüksek karbon içerikli bir materyal olmasidır (Lehmann ve Joseph 2009).

Küresel olarak yıllık tarımsal atık üretiminin 2009 yılında 988 milyon ton olduğu tahmin edilmiştir. Tarımsal atıkların açıkta yakılması veya arazide yığılarak çürümeye terk edilmesi çeşitli çevresel sorunlara neden olmaktadır (Mahawar ve ark., 2015). Ekonomisinde tarımsal üretimin oldukça önemli payı olan ülkemizde de tarımsal üretim atıklarının bir kısmı yakacak ve yem endüstrisinde kullanılmakta, ancak önemli bir kısmı ise çevreye zarar verecek şekilde çürümeye terk edilmekte veya yakılarak yok edilmektedir (Şekil 1 ve 2).

Bu çalışmasının amacı, yedi farklı biyokütlenin 3 farklı sıcaklıkta $(300,400$ ve $600 \stackrel{\circ}{\circ}$ ) pirolizi ile elde edilen biyoçarların çeşitli fiziksel ve kimyasal özelliklerinin belirlenmesi ve karşılaştırılmasının yapılmasıdır. Günümüzde oldukça geniș bir yelpazede yer alan araștırmaçların ilgi odağı haline gelmiș olan biyoçar konusunda en önemli eksikliklerden bir tanesi, farklı biyokütle ve farklı piroliz ortamlarında elde edilen 
biyoçarın özelliklerinin belirlenmemiş olmasıdır. $\mathrm{Bu}$ nedenle, tarımsal atıklardan türetilen biyoçarın topraktaki maksimum etkinliği sağlayacak biyoçarın üretiminde kullanılacak optimum piroliz sıcaklığın belirlenmesi çalışmanın ana hedefidir. Çalışmada, öncelikle bölgede temin edilen ve bol miktarda üretilebilen domates atıkları (sap, gövde ve yaprakları), kavak talaşı, buğday samanı, mısır koçanı, fasulye atıkları, çeltik kavuzu ve büyükbaş hayvan gübresi kullanılmıştır. Biyoçarın çeşitli kullanımlardaki etkinliği, iyonik kirleticileri adsorbe etme gibi biyoçarın yüzey kimyası ile yakından ilişkilidir (Banik ve ark., 2018). Bu nedenle; tarımsal üretimde ve diğer alanlarda potansiyel kullanımları için yol gösterici bilgilerin elde edileceği bu çalışma sonuçları, sonradan yapılacak uygulamalı araştırmalar için de önemli bir altlık görevi görecektir.
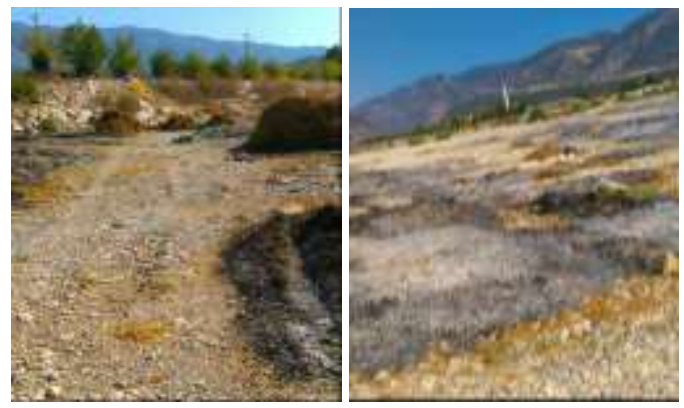

Şekil 1. Antalya-Demre'de 2015 yılı üretim sezonu sonunda çevreye çürümeye terk edilen ve yakılan domates atıkları

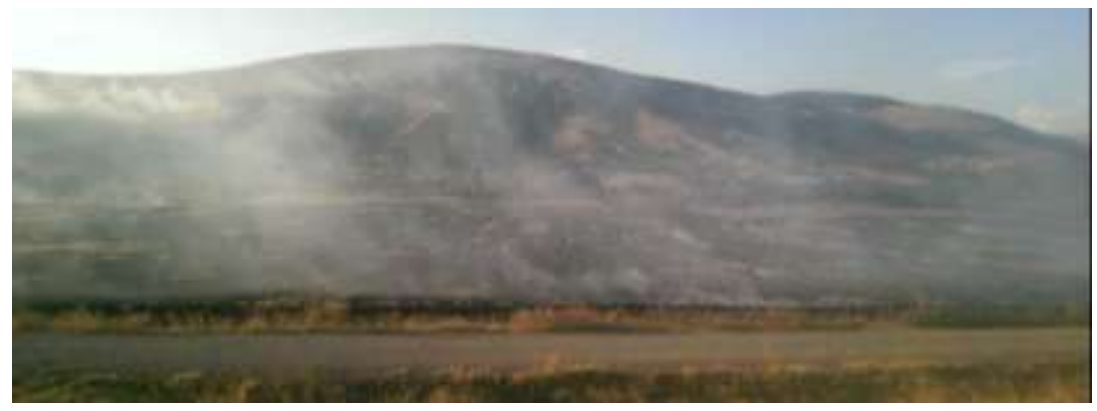

Şekil 2. Buğday hasat atıklarının yeni ekim sezonu öncesinde yakılması (Eylül-2015, Alaca-Çorum)

\section{Materyal ve Yöntem}

\section{Materyal}

Çalışmada, bölgede temin edilme potansiyeli yüksek olan tarımsal atıklardan domates hasat atıkları, fasulye hasat atıkları, mısır koçanı, buğday sapı, çeltik kavuzu, büyük baş hayvan gübresi ve kavak ağacı talaşı hammadde olarak kullanılmıștır. Hammadde olarak kullanılan materyallerin piroliz öncesine ait bir kısım özellikleri Çizelge 1'de verilmiştir (Bayram, 2016).

Çizelge 1. Kullanılan hammaddelerin piroliz öncesi belirlenen bir kısım özellikleri (Bayram, 2016)

\begin{tabular}{|c|c|c|c|c|c|c|c|c|c|c|}
\hline \multirow{2}{*}{ Hammadde } & \multirow[t]{2}{*}{$\mathrm{pH}$} & \multirow{2}{*}{$\begin{array}{c}\mathrm{EC} \\
\mathrm{dS} \mathrm{m}^{-1} \\
\end{array}$} & $\mathrm{P}$ & $\mathrm{K}$ & $\mathrm{Ca}$ & $\mathrm{Mg}$ & $\mathrm{Cu}$ & $\mathrm{Mn}$ & $\mathrm{Fe}$ & $\mathrm{Zn}$ \\
\hline & & & \multicolumn{3}{|c|}{ g kg-1 } & & & \multicolumn{3}{|c|}{$\mathrm{mg} \mathrm{kg}^{-1}$} \\
\hline Büyükbaş & 9.13 & 9.35 & 4.34 & 10.4 & 55.4 & 12.0 & 33.1 & 327.6 & 1450.5 & 83.40 \\
\hline Çeltik Kavuzu & 6.80 & 5.46 & 0.33 & 4.5 & 1.2 & 0.8 & 4.1 & 154.3 & 112.6 & 18.35 \\
\hline Domates Atıkları & 7.18 & 5.59 & 1.37 & 19.7 & 26.1 & 6.8 & 75.1 & 60.0 & 334.0 & 45.76 \\
\hline Fasulye Atıkları & 7.85 & 4.94 & 2.27 & 24.3 & 30.9 & 8.0 & 15.1 & 78.5 & 845.4 & 36.17 \\
\hline Kavak Talaşı & 6.91 & 2.92 & 0.24 & 2.1 & 3.6 & 0.8 & 2.8 & 15.9 & 89.5 & 20.28 \\
\hline Misır Koçanı & 5.88 & 9.81 & 0.41 & 7.0 & 0.4 & 0.6 & 4.3 & 15.9 & 107.6 & 43.43 \\
\hline Buğday Samanı & 7.57 & 3.37 & 0.58 & 14.4 & 4.9 & 1.3 & 4.4 & 56.9 & 125.2 & 12.86 \\
\hline
\end{tabular}

\section{Yöntem}

Yöntem biyoçar üretilmesi, hammadde ve biyoçarların özelliklerinin belirlenmesi ve veri değerlendirmesi şeklinde üç kısımdan oluşmaktadır.

\section{Biyoçar Üretilmesi}

Hammaddeler oda sıcaklığında kurutulmuş ve bir öğ̈tücüde öğütüldükten sonra piroliz işlemine tabi tutulmuştur. Biyoçar üretiminde, yanma haznesi geniş olan bir kül fırını kullanılmıștır. Öğütülmüș ve oda sıcaklığında kurutulmuş olan hammaddeler biyoçar üretim için kromdan yapılmış 2 litre hacimli kaplara doldurulmuş ve bu kaplar kül fırınına yerleştirilmiştir. Biyoçarlar yavaş piroliz işlemi ile yaklaşık 300, 400 ve $600{ }^{\circ} \mathrm{C}$ sıcaklıklarda üretilmiştir. Biyoçar üretimi esnasında ortaya çıkan katran ve singazlar depolanmamıştır. Biyoçar üretimi esnasında sıcaklık artışı $10^{\circ} \mathrm{C} /$ dakika olacak şekilde ayarlanmış, piroliz gazı çıkışı tamamlanana kadar beklenmiştir. Pirolizi tamamlanan örnekler kül fırınının içerisinde kapalı kaplarda tutulmuş ve tam soğuma gerçekleştikten sonra çıkarılmıştır. Analizler öncesinde biyoçarlar 1 mm'lik elekten geçirilmiş ve saklama kaplarına alınarak laboratuvar analizleri için muhafaza edilmiştir. 


\section{Biyoçarların karekterizasyonu}

Elde edilen biyoçarların bir kısım fiziksel ve kimyasal özellikleri standart yöntemler ile belirlenmiştir. Her örnek 3 paralel şeklinde analiz edilmiştir. Bu çalışmada belirlenen özellikler ve kullanılan yöntemler aşağıda verilmiştir.

Biyoçarın verimi (ym), karbonize edilen ürünün kütlesinin (mcarb) ham biyokütlenin kütlesine (mbiom) oranıdır (Weber ve Quicker, 2018). Böylece orijinal kütlenin ne kadarının pirolizin katı tortusunda kaldığı anlaşılabilir. Biyoçar verimi, piroliz öncesi ve sonrası krom kaplarda konulan hammadde ve biyoçarın ağırlıkları belirlenmiş ve biyoçarın hammaddeye oranı biyoçar verimi olarak kayıt edilmiştir.

$$
y m=\frac{\text { maarb }}{\text { mbiom }} * 100
$$

Spesifik yüzey alanı, Etilen Glikol Monoetilen Eter (EGME) yöntemine göre yapılmıştır (Cerato ve Lutenegger, 2002). Yarayışlı su içeriği, tarla kapasitesinde tutulan nem içeriğinden solma noktasındaki nem içeriğinin çıkarılması ile hesaplanmıştır (Klute, 1986).

Biyoçarın pH ve EC'si 1/2 (biyoçar/saf su) oranındaki karışımda McLean (1982) tarafından toprak örnekleri için tavsiye edilen standart yönteme uygun bir şekilde taşınabilir bir pH/EC metre kullanılarak belirlenmiștir. Katyon değișim kapasitesi, amonyum asetat yöntemine göre yapılmış ve sodyum konsantrasyonları fleym fotometrede belirlenmiştir (Sumner ve Miller, 1996). Toplam karbon ve azot içerikleri, kuru yakma yöntemiyle Elementel Analiz cihazı kullanılarak belirlenmiştir (Tabatabai, 1994).

Biyoçar örneklerinin toplam fosfor, kalsiyum, magnezyum, potasyum, çinko, demir, bakır ve mangan konsantrasyonları için örnekler agat değirmeninde ögütülmüş, her birinden $0.2 \mathrm{~g}$ tartılmış ve sonrasında mikro dalgada yaş yakma metoduna göre $\mathrm{H}_{2} \mathrm{O}_{2}-\mathrm{HNO}_{3}$ asit karıșımı ile yakılmıștır. Yanma sonrası elde edilen süzüklerdeki konsantrasyonlar ICO-OES cihazında belirlenmiştir (Kacar ve İnal, 2008).

\section{Veri değerlendirmesi}

Her bir biyoçar materyalinin belirlenen özelliklerine ait tanımlayıcı istatistik parametreleri belirlenmiștir. Biyoçarların özellikleri açısından benzerlik ve farklılıklarını ortaya koyabilmek amacı ile tek yönlü varyans analizi (ANOVA) yapılmıștır. ANOVA sonrasında, istatistiksel olarak farklılıkları bulunmayan biyoçarların gruplandırılması homojenlik testi olan DUNCAN gruplaması ile yapılmıştır.

\section{Bulgular ve Tartışma}

\section{Biyoçarların Fiziksel Özellikleri}

\section{Biyoçar Verimi}

Belirli bir biyokütlenin pirolizinden elde edilebilecek ürün miktarı, piroliz işleminin gerçekleştiği ortamın şartlarına, pirolizin gerçekleștiği sıcaklığa ve materyalin piroliz ünitesinde kalma süresine bağlı olarak değişmektedir (Weber ve Quicker, 2018). Üç farklı sıcaklıkta üretilen biyoçarların verimlerine ait değerler Çizelge 2'de verilmiştir. Piroliz sıcaklığının $300^{\circ}{ }^{\circ} C^{\prime}$ den $600{ }^{\circ}{ }^{\circ}$ 'ye çlkarılması tüm biyoçar çeşitlerinde üretilen biyoçar miktarında düşüșe neden olmuştur. Biyoçar verimi $300{ }^{\circ} C^{\prime}$ de $\% 35.2$ ile $\% 53.9,400{ }^{\circ} C^{\prime}$ de \%21.8 ile \%46.1 ve 600 ํ'de ise \%18.4 ile \%42.6 arasında değişmiştir (Çizelge 2). Biyoçar veriminin yüksek olabilmesi için daha yüksek lignin içeren biyokütlenin kullanılması gerekmektedir. Hemiselülozların ve selülozun düşük yapısal stabiliteleri, bu bileşenlerin sıcaklıkla birlikte daha erken bozulmasına yol açar. Bu bileșenler parçalanarak yoğunlaşabilir gazlara dönüşürken, daha kararlı olan lignin biyoçarın verimine katkıda bulunur (Pereira ve ark., 2011). Bu durumda, biyoçar üretiminde kullanılan hammaddelerden çeltik kavuzunun lignin içeriğinin, aksine kavak talaşının ise hemiselüloz ve selüloz içeriğinin yüksek olduğu söylenebilir.

Piroliz sıcaklığındaki artışla birlikte meşe, çam, şeker kamışı ve yerfıstığı kabuğundan üretilen biyoçarların veriminde önemli düzeyde düşüş olduğuna dair araştırmalar yayınlanmıștır (Zhang ve ark., 2016). Yakın zamanda yayınlanan bir başka araştırmada da Chandra ve Bhattacharya (2019) da çeltik sapının piroliz sıcaklığının $400{ }^{\circ}{ }^{\circ}$ 'den 700 o C'ye çıkarılması ile biyoçar veriminin \%45'den \%34'e düştüğünü belirtmişlerdir. Biyoçar verimlerinin sıcaklık artışıyla azalması, piroliz işlemi esnasında biyoçarın temel birincil yapısının bozulmasından kaynaklandığı düşünülmektedir. Düşük piroliz sıcaklığında, hammadde kısmen yandığından dolayı, daha yüksek verim elde edilmektedir. Ancak yüksek sıcaklık biyokütlenin çok daha fazla yanmasına yol açtığından elde edilen biyoçarın verimi de düşmektedir (Joseph et al., 2010; Angin, 2013). Sarfraz ve ark. (2019)'da mantar hasat atıklarından üretilen biyoçar veriminin ve bir kısım özelliklerinin temel olarak sıcaklıkla birlikte değiş̧iğini bildirmişlerdir. Sıcaklık artışı ile biyoçar verimindeki azalmanın en fazla olduğu biyoçar çeşidi \%53.2 ile kavak talaşı iken en düşük orandaki azalma \%19.5 ile 
fasulye bitkisinin atıklarında gerçekleşmiştir. Biyoçarların farklı piroliz sıcaklıkları altındaki genel ortalamalarına bakıldığında $300{ }^{\circ}{ }^{\circ} C^{\prime}$ de $\% 41.3$ olan verim, $400{ }^{\circ} C^{\prime}$ de $\% 34.3$ ve $600{ }^{\circ} C^{\prime}$ de ise \%29.9'a düşmüştür. Farklı sıcaklıklarda üretilen biyoçarların verimlerinin karşılaştırıldığı ANOVA testi, farklılığın istatistiksel olarak önemli düzeyde $(\mathrm{P}<0.05)$ olduğunu göstermektedir (Çizelge 2$)$.

Çizelge 2. Farklı sıcaklıklarda üretilen biyoçarların verimleri

\begin{tabular}{|c|c|c|c|c|c|c|c|c|}
\hline \multirow[t]{2}{*}{ Sicaklık ${ }^{\circ} \mathrm{C}$} & Büyükbaş & Çeltik & Domates & Fasulye & $\begin{array}{l}\text { Kavak } \\
\text { Talașı } \\
\end{array}$ & $\begin{array}{l}\text { Misır } \\
\text { Koçanı }\end{array}$ & $\begin{array}{l}\text { Buğday } \\
\text { Samanı }\end{array}$ & \multirow{2}{*}{$\begin{array}{l}\text { Genel } \\
\text { Ort. } \pm\end{array}$} \\
\hline & \multicolumn{7}{|c|}{$\%$} & \\
\hline 300 & 44.9 & 53.9 & 45.5 & 39.9 & 39.4 & 35.2 & 39.4 & $41.3 \mathrm{a}$ \\
\hline 400 & 36.0 & 46.1 & 38.9 & 33.3 & 21.8 & 31.9 & 33.3 & $34.3 \mathrm{ab}$ \\
\hline 600 & 32.2 & 42.6 & 32.4 & 32.1 & 18.4 & 26.2 & 28.0 & $29.9 b$ \\
\hline$\%$ Fark $(300-600)$ & -28.2 & -20.9 & -28.8 & -19.5 & -53.2 & -25.7 & -29.1 & \\
\hline
\end{tabular}

ANOVA (P değeri) $0.02 *$

£Duncan gruplamasında farklı harfler ile gösterilen ortalamalar arasında $\mathrm{P}<0.05$ düzeyinde önemli farklıdır. *, ** Uygulamalar arasındaki fark sırası ile $\mathrm{P}<0.01$ ve $\mathrm{P}<0.05$ düzeyinde önemlidir.

\section{Biyoçarların Spesifik Yüzey Alanları}

Farklı piroliz sıcaklığında 7 adet hammaddeden üretilen biyoçarların spesifik yüzey alanlarına (SYA) ait değerler Çizelge 3'te verilmiştir. Hammaddenin $400 \stackrel{\circ}{\circ} \mathrm{C}$ civarında pirolizi esnasında uçucu maddenin uzaklaşmaya başlaması ile mikro gözenek sayısının önemli ölçüde arttığı bildirilmektedir (Chen ve ark., 2014). Bu durumun biyoçarın gözenek hacminde ve yüzey alanında bir artışa neden olacağı rapor edilmiştir. Çeltik, fasulye atıkları ve buğday samanı biyoçarının yüzey alanlarında $300{ }^{\circ} \mathrm{C}$ ve $400{ }^{\circ} \mathrm{C}$ piroliz sıcaklıkları arasındaki farklılığın da uçucu gazların uzaklaşması ile meydana gelen yüzey alanı artışı olduğu düşünülmektedir (Çizelge 3). Daha yüksek sıcaklıklarda ise yapısal düzende değişiklik, komşu gözeneklerin genişlemesi ve birleştirilmesi yüzey alanında bir azalmaya yol açmaktadır. Ayrıca, biyoçardaki gözenekler, sıkıştırılma, yumuşatılma, erime, birleşme ve kömürleşme işlemleri esnasında da daralmaktadır (Chen ve ark., 2014). Bu çalışmada üretilen 7 biyoçar çeşidinde de piroliz sıcaklığının $400{ }^{\circ} C^{\prime}$ 'den $600{ }^{\circ} C^{\prime}$ ye çıkarılması SYA'nın önemli düzeyde azalmasına yol açmıştır. Piroliz sıcaklığı biyoçarların SYA üzerine istatistiksel olarak önemli düzeyde etki etmiş ve farklılaşmalarına neden olmuştur (Çizelge 3). Özellikle $400{ }^{\circ} C^{\prime}$ den $600{ }^{\circ} C^{\prime} y e$ çıkarılan piroliz sıcaklığı SYA'nın $450.1 \mathrm{~m}^{2} \mathrm{~g}$-1'den $252.2 \mathrm{~m}^{2} \mathrm{~g}^{-1}$ 'ye düşmesine neden olmuştur (Çizelge 3).

Çizelge 3. Farklı sıcaklıklarda üretilen biyoçarların spesifik yüzey alanları $\left(\mathrm{m}^{2} \mathrm{~g}^{-1}\right)$

\begin{tabular}{|c|c|c|c|c|c|c|c|c|}
\hline \multirow[t]{2}{*}{ Sicaklık ${ }^{\circ} \mathrm{C}$} & Büyükbaş & Çeltik & Domates & Fasulye & $\begin{array}{l}\text { Kavak } \\
\text { Talaşı }\end{array}$ & $\begin{array}{l}\text { Misır } \\
\text { Koçanı }\end{array}$ & $\begin{array}{l}\text { Buğday } \\
\text { Samanı }\end{array}$ & \multirow[t]{2}{*}{$\begin{array}{l}\text { Genel } \\
\text { Ort. } \pm\end{array}$} \\
\hline & \multicolumn{7}{|c|}{$\%$} & \\
\hline 300 & 510.1 & 439.8 & 680.0 & 611.8 & 758.3 & 752.3 & 625.7 & $444.5 a$ \\
\hline 400 & 418.6 & 688.4 & 426.9 & 682.5 & 713.7 & 651.3 & 644.5 & $450.1 \mathrm{a}$ \\
\hline 600 & 219.8 & 204.3 & 273.4 & 237.3 & 250.8 & 325.4 & 345.0 & $252.2 \mathrm{~b}$ \\
\hline \%Fark (300-600) & -56.9 & -53.6 & -59.8 & -61.2 & -66.9 & -56.7 & -44.9 & \\
\hline
\end{tabular}

ANOVA (P değeri) $0.00^{* *}$

£Duncan gruplamasında farklı harfler ile gösterilen ortalamalar arasında $\mathrm{P}<0.05$ düzeyinde önemli farklıdır. *, ** Uygulamalar arasındaki fark sırası ile $\mathrm{P}<0.01$ ve $\mathrm{P}<0.05$ düzeyinde önemlidir.

\section{Biyoçarların Su Tutma Kapasiteleri}

Bir malzemenin su tutma kabiliyetini gösteren su tutma kapasitesi gözenekliliğe ve gözeneklerin birbirine bağlı olmasına bağlıdır. Bu nedenle, yüksek sıcaklıkta üretilen biyoçarların gözenekli yapılarında daha fazla su tutması beklenebilir (Gray ve ark., 2014). Düşük sıcaklıkta üretilen biyoçarlar da gözenekli bir yapıya sahip olsalar da daha küçük gözenek boyutu, daha az birbirine bağlı olma ve gözenekleri tıkayan katran bileşenleri nedeniyle kolayca erişilebilir olmayabilir (Das ve ark., 2015). Piroliz sırasında gerçekleșen fonksiyonel grupların miktarındaki azalma materyalin suya afinitesini değiştirir. Yine piroliz esnasında gözeneklilikte meydana gelen artış, adsorbe edilebilecek su miktarının değişmesine neden olur (Weber ve Quicker, 2018). Üretilen biyoçarların tarla kapasitesi, solma noktası ve yarayışlı su içerikleri büyük baş hayvan gübresinden üretilen biyoçar haricinde sıcaklık artışı ile birlikte artmıştır (Çizelge 4). Tarla kapasitesi, solma noktası ve yarayışlı su içeriklerindeki artışın en yüksek olduğu biyoçar tipi ise kavak talaşı olmuştur.

Biyoçarlarda görülen hidrofobiklik, yüzey fonksiyonel gruplarının bir sonucudur, diğer yandan su tutma kapasitesi biyoçarın gözenekliliğine bağlıdır. Bu özellikler biyoçarın su tutması ile ilgili olarak birbirleri ile çelişen etkilere neden olurlar ve çoğu zaman açıkça birbirinden ayırt edilemezler (Weber ve Quicker, 2018). 
Piroliz sıcaklığının artışı üç nem içeriğinde de istatistiksel olarak önemli olmamakla birlikte artışa neden olmuștur (Çizelge 4). Tarla kapasitesi olarak tanımlanan 1/3 atmosfer basınç altında tutulan nem miktarında $300{ }^{\circ} C^{\prime}$ den $600{ }^{\circ} C^{\prime}$ ye çıkarılan sıcaklık tutulan nem miktarının \%41.5 oranında artışına yol açmıștır. Bu durum yarayışlı suyunda \%54.9 oranında artışına neden olmuştur (Çizelge 4).

Çizelge 4. Farklı sıcaklıklarda üretilen biyoçarların tarla kapasitesi, solma noktası ve yarayışlı su içerikleri

\begin{tabular}{|c|c|c|c|c|c|c|c|c|}
\hline \multirow[t]{2}{*}{ Sicaklık ${ }^{\circ} \mathrm{C}$} & Büyükbaş & Çeltik & Domates & Fasulye & $\begin{array}{l}\text { Kavak } \\
\text { Talaşı }\end{array}$ & $\begin{array}{l}\text { Mısır } \\
\text { Koçanı }\end{array}$ & $\begin{array}{l}\text { Buğday } \\
\text { Samanı }\end{array}$ & \multirow[t]{2}{*}{$\begin{array}{l}\text { Genel } \\
\text { Ort. } \pm\end{array}$} \\
\hline & \multicolumn{7}{|c|}{ Tarla Kapasitesi (\%) } & \\
\hline 300 & 48.2 & 21.3 & 80.3 & 80.6 & 24 & 56.7 & 59.9 & $53.0 \mathrm{a}$ \\
\hline 400 & 61.5 & 68.4 & 62.8 & 43.2 & 33.8 & 73.7 & 73.8 & $59.6 a$ \\
\hline 600 & 43.4 & 39.7 & 73.5 & 91.99 & 111.2 & 65.5 & 99.2 & $75.0 \mathrm{a}$ \\
\hline$\%$ Fark (300-600) & -10.0 & 86.4 & -8.5 & 14.1 & 363.3 & 15.5 & 65.6 & 41.5 \\
\hline \multirow[t]{2}{*}{ ANOVA (P değeri) } & $0.210 ̈ \mathrm{D}$ & & & & & & & \\
\hline & \multicolumn{7}{|c|}{ Solma Noktası (\%) } & \\
\hline 300 & 24.4 & 14.4 & 27.5 & 25.2 & 12.7 & 28.2 & 29.3 & $23.1 \mathrm{a}$ \\
\hline 400 & 21.9 & 26.3 & 21.6 & 32.7 & 11.9 & 34.5 & 28.3 & $25.3 a$ \\
\hline 600 & 19.9 & 21.2 & 26.6 & 29.9 & 26.8 & 30.7 & 45.1 & $28.6 a$ \\
\hline$\%$ Fark (300-600) & -18.4 & 47.2 & -3.3 & 18.7 & 111.0 & 8.9 & 53.9 & 23.8 \\
\hline \multirow[t]{2}{*}{ ANOVA (P değeri) } & $0.410 ̈ \mathrm{D}$ & & & & & & & \\
\hline & \multicolumn{7}{|c|}{ Yarayıșlı Su İçeriği (\%) } & \\
\hline 300 & 23.8 & 6.9 & 52.8 & 55.4 & 11.3 & 28.5 & 30.6 & $29.9 a$ \\
\hline 400 & 39.6 & 42.1 & 41.2 & 10.5 & 21.9 & 39.2 & 45.5 & $34.3 \mathrm{a}$ \\
\hline 600 & 23.5 & 18.5 & 46.9 & 62.09 & 84.4 & 34.8 & 54.1 & $46.3 \mathrm{a}$ \\
\hline$\%$ Fark (300-600) & -1.3 & 168.1 & -11.2 & 12.1 & 646.9 & 22.1 & 76.8 & 54.9 \\
\hline ANOVA (P değeri) & $0.260 ̈ \mathrm{D}$ & & & & & & & \\
\hline
\end{tabular}

\section{Biyoçarların Kimyasal Özellikleri}

\section{Biyoçarların pH ve Elektriksel İletkenlikleri}

Biyoçar toprak katkı maddesi olarak kullanıldığında pH değeri tarımsal uygulamalar için önemli bir özelliktir. Ayrıca, pH piroliz ile üretilen biyokömürün hidrotermal karbonizasyon yoluyla üretilen kömürlerden önemli düzeyde farklı kllan özelliklerden biridir. Hidrotermal karbonizasyon yoluyla üretilen hidroçarda organik asitler bulunur, bu da hidroçarın asidik hale gelmesine neden olur. Piroliz edilmemiş biyokütlenin pH değerleri tipik olarak 5 ila 7.5 arasında değişir (Weber ve Quicker, 2018). Piroliz sırasında yapıdan ağırlıklı olarak karboksil, hidroksil veya formil grupları gibi asidik karakterli fonksiyonel gruplar ayrılırlar. Geride kalan katı kısımda ise daha işlevsel gruplar serbest bırakılır. Aynı zamanda külün oransal içeriği de piroliz işlemi sırasında artar. Dolayısıyla, karbonlaşma derecesi arttıkça materyalin pH değeri de artar (Ahmad ve ark., 2012; Ippolito ve ark., 2012).

Biyoçarın pH değeri üzerinde en etkili faktör olduğu belirtilen, piroliz sıcaklığının artışı tüm biyoçar çeşitlerinde pH'nın artmasına yol açmıştır. Bu durum, asidik reaksiyona giren fonksiyonel grupların çoğunun, karbonizasyon işleminde oldukça erken salındığının bir göstergesidir (Weber ve Quicker, 2018). Bu artışın en yüksek olduğu biyoçar tipi çeltik (\%34.6 artış) iken en düşük olduğu biyoçar çeşidi mısır koçanı (\%13.3 artış) olmuştur. En düşük pH değerleri 300, 400 ve $600{ }^{\circ} \mathrm{C}$ sıcaklıklarda sırası ile 8.34 (kavak talaşı), 8.79 (mısır koçanı) ve 9.76 (kavak talaşı)'dır. En yüksek pH değerlerine sahip biyoçar tipleri ise $300{ }^{\circ} \mathrm{C}^{\prime} \mathrm{de}$ büyük baş hayvan gübresi (9.97), $400{ }^{\circ}{ }^{\circ}$ 'de fasulye atıkları (10.58) ve $600{ }^{\circ}{ }^{\circ}$ 'de ise fasulye atıkları (12.09)'dır (Çizelge 5). Düşük sıcaklıkta üretilen biyoçar genellikle daha asidik özellikte iken daha yüksek sıcaklıklarda alkali hale geldiği diğer birçok araştırmacı tarafından da bildirilmiştir (Sun ve ark., 2017).

$\mathrm{Bu}$ çalışmada belirlenen $\mathrm{pH}$ aralıkları yüksek piroliz sıcaklığında şeker pancarı atıklarından, atık çamurundan ve şeker kamışı atıklarından üretilen biyoçar için bildirilen değerlere benzemektedir (Inyang ve Dickenson, 2015; Yuan ve ark., 2011). Piroliz sıcaklığının pH üzerindeki etkisi (1) artan sıcaklıkla birlikte, karbonatlar, oksitler ve hidroksit gibi alkali türlerle ilişkili olabilecek küllerde bazik katyonların zenginleşmesi (Yuan ve ark., 2011; Singh ve ark., 2011) ve (2) asidik yüzey fonksiyonel gruplarının konsantrasyonunda bir azalmanın meydana gelmesi (Singh ve ark., 2011) ile ilişkilendirilmektedir. Zhang ve ark. (2017)'da piroliz sıcaklığının $350{ }^{\circ} \mathrm{C}$ 'den $900{ }^{\circ} \mathrm{C}$ 'ye artışı biyokütlenin sıcaklıkla birlikte çatlaması esnasında hidrojen iyonlarının salınımının pH'nın artmasına yol açtığını bildirmişler ve pH'nın \%35.41 oranında arttığını rapor etmişlerdir. Piroliz sıcaklığındaki artış biyoçarın pH değerlerinde önemli düzeyde 
$(\mathrm{P}<0.01)$ farklılaşmaya neden olurken, EC değerlerinde istatistiksel olarak önemli olmayan bir farklılaşmaya yol açmıştır (Çizelge 5). Piroliz sıcaklığı $300{ }^{\circ} \mathrm{C}$ olduğunda ortalama 9.08 olan pH değeri, sıcaklık $600{ }^{\circ} C^{\prime} y e$ çıkarıldığında ortalama 11.11'e yükselmiştir (Çizelge 5).

Çizelge 5. Farklı sıcaklıklarda üretilen biyoçarların pH ve elektriksel iletkenlik değerleri

\begin{tabular}{|c|c|c|c|c|c|c|c|c|}
\hline \multirow[t]{2}{*}{ Sicaklık ${ }^{\circ} \mathrm{C}$} & Büyükbaş & Çeltik & Domates & Fasulye & $\begin{array}{l}\text { Kavak } \\
\text { Talașı }\end{array}$ & $\begin{array}{l}\text { Misır } \\
\text { Koçanı }\end{array}$ & $\begin{array}{l}\text { Buğday } \\
\text { Samanı }\end{array}$ & \multirow[t]{2}{*}{$\begin{array}{l}\text { Genel } \\
\text { Ort. } \pm\end{array}$} \\
\hline & \multicolumn{7}{|c|}{$\mathrm{pH}$} & \\
\hline 300 & 9.97 & 8.32 & 9.31 & 9.52 & 8.34 & 8.97 & 9.10 & $9.08 \mathrm{a}$ \\
\hline 400 & 10.52 & 9.21 & 10.18 & 10.58 & 9.26 & 8.79 & 9.94 & $9.78 \mathrm{a}$ \\
\hline 600 & 11.86 & 11.2 & 12.0 & 12.09 & 9.76 & 10.16 & 10.70 & $11.11 \mathrm{~b}$ \\
\hline \%Fark (300-600) & 19.0 & 34.6 & 28.9 & 27.0 & 17.0 & 13.3 & 17.6 & \\
\hline \multirow[t]{2}{*}{ ANOVA (P değeri) } & $0.00^{* *}$ & & & & & & & \\
\hline & \multicolumn{7}{|c|}{ Elektriksel İletkenlik (dS m-1) } & \\
\hline 300 & 2.71 & 0.387 & 5.94 & 6.43 & 0.2 & 1.382 & 0.845 & $2.56 \mathrm{a}$ \\
\hline 400 & 3.79 & 0.409 & 4.33 & 4.53 & 0.17 & 2.44 & 1.086 & $2.39 \mathrm{a}$ \\
\hline 600 & 4.0 & 1.171 & 4.17 & 4.73 & 0.808 & 4.38 & 2.74 & $3.14 \mathrm{a}$ \\
\hline \%Fark (300-600) & 47.6 & 202.6 & -29.8 & -26.4 & 304.0 & 216.9 & 224.3 & \\
\hline ANOVA (P değeri) & $0.780 ̈ \mathrm{D}$ & & & & & & & \\
\hline
\end{tabular}

\section{Biyoçarların Katyon Değişim Kapasiteleri}

Katyon değişim kapasitesi (KDK), çoğunlukla malzemenin yük yoğunluğuna ve sulu çözeltideki değiştirilebilir iyonların bolluğuna bağlıdır (Brady ve Weil, 1999). Biyoçar çeşidine bağlı olarak önemli ölçüde değişkenlik gösteren KDK değerleri $300{ }^{\circ}{ }^{\prime}{ }^{\prime} l i k$ piroliz sıcaklığında $33.47 \mathrm{cmolc} \mathrm{kg}^{-1}{ }^{\prime}$ den $88.16 \mathrm{cmolc}$ $\mathrm{kg}^{-1}{ }^{\prime} \mathrm{a}, 400{ }^{\circ} \mathrm{C}^{\prime}$ de $41.87 \mathrm{cmolc} \mathrm{kg}^{-1}{ }^{\prime}$ den $78.68 \mathrm{cmolc} \mathrm{kg}{ }^{-1} \mathrm{e}$ ve $600{ }^{\circ} \mathrm{C}^{\prime}$ de ise $23.27 \mathrm{cmolc} \mathrm{kg-1'}$ den $68.03 \mathrm{cmolc}$ kg-1'e kadar değişkenlik göstermiștir (Çizelge 6). Piroliz sıcaklığının artışı buğday samanı biyoçarı haricindeki tüm biyoçarların KDK'sının azalmasına neden olmuștur. Yüklü yüzey fonksiyonel grupların ve yüzey alanının bir birleşimi olan KDK'si, nispeten düşük piroliz sıcaklıklarda üretilen biyoçarlarda daha yüksek olduğu bildirilmiştir. Düşük sıcaklıklarda biyoçarın yüzey alanı hammaddeye kıyasla çok daha yüksek hale gelirken, negatif yük sağlayacak olan yeterli miktarda fonksiyonel grubun yapı içerisinde kaldı̆̆ belirtilmiştir (Weber ve Quicker, 2018). Mukherjee ve ark. (2011), farklı pH seviyelerine sahip (1.5-7.5) meşe, çam ve ot gibi hammaddelerden 250 C'lik piroliz sıcaklığında üretilen biyoçarların ortalama KDK'sinin $51.9 \pm 15.3$ cmolc $\mathrm{kg}^{-1}$ olduğunu ve piroliz sıcaklığının $400{ }^{\circ} \mathrm{C}$ ve $650{ }^{\circ} \mathrm{C}$ 'ye yükseltilmesi ile biyoçarların ortalama KDK'lerinin sırasiyla $16.2 \pm 6.0$ ve $21.0 \pm 17.2$ cmolc kg-1 olduğunu bildirmişlerdir. Benzer şekilde, Sarfraz ve ark. (2019)'da mantar hasat atıklarından üretilen biyoçarın KDK'nin sıcaklığın $400{ }^{\circ} C^{\prime}$ den 700 o C'ye çıkarılması ile 32.24 cmolc $\mathrm{kg}^{-1}$ 'dan 22.70 cmolc $\mathrm{kg}^{-1}$ 'a düştüğünü ve KDK'yı etkileyen en önemli faktörlerin piroliz sıcaklığı ve hammadde tipi olduğunu rapor etmişlerdir. Asidik fonksiyonel gruplarla ilişkili aromatik C yapılarının doğası biyoçarın KDK'si ve adsorpsiyon kapasitesini etkileyebileceği belirtilmiştir (Kloss ve ark., 2012).

Piroliz sıcaklığı biyoçarların ortalama KDK değerleri üzerine önemli bir etki yapmamıştır (Çizelge 6). Piroliz sıcaklığı $300{ }^{\circ} \mathrm{C}$ olduğunda ortalama $32.6 \mathrm{cmolc} \mathrm{kg}^{-1}$ olan KDK değeri, $400{ }^{\circ}{ }^{\prime} \mathrm{C}^{\prime}$ lik piroliz sıcaklığında 45.4 cmolc kg-1'a yükselmiş, ancak sıcaklığın $600^{\circ}{ }^{\circ}$ 'ye çıkarılması ile daha fazla artış olmamıştır. Tam aksine KDK değeri 41.5 cmolc kg-1 olmuştur (Çizelge 6).

Çizelge 6. Farklı sıcaklıklarda üretilen biyoçarların katyon değişim kapasiteleri (cmolc kg-1)

\begin{tabular}{lllllllll}
\hline Sıcaklık ${ }^{\circ} \mathrm{C}$ & Büyükbaş & Çeltik & Domates & Fasulye & $\begin{array}{l}\text { Kavak } \\
\text { Talaşı }\end{array}$ & $\begin{array}{l}\text { Mısır } \\
\text { Koçanı }\end{array}$ & $\begin{array}{l}\text { Buğday } \\
\text { Samanı }\end{array}$ & $\begin{array}{l}\text { Genel } \\
\text { Ort.土 }\end{array}$ \\
\hline 300 & 76.32 & 33.47 & 78.21 & 88.16 & 35.99 & 41.97 & 48.93 & $32.6 \mathrm{a}$ \\
400 & 66.20 & 43.53 & 78.68 & 53.44 & 41.87 & 50.56 & 51.55 & $45.4 \mathrm{a}$ \\
600 & 42.51 & 31.98 & 52.73 & 39.56 & 23.27 & 40.06 & 68.03 & $41.5 \mathrm{a}$ \\
\hline \%Fark (300-600) & -44.3 & -4.4 & -32.6 & -55.1 & -35.3 & -4.5 & 39.0 & \\
\hline
\end{tabular}

ANOVA (P değeri) $0.270 ̈ \mathrm{D}$

\pm Duncan gruplamasında farklı harfler ile gösterilen ortalamalar arasında $\mathrm{P}<0.05$ düzeyinde önemli farklıdır. ÖD Uygulamalar arasındaki fark önemli değildir.

Piroliz sıcaklığının artışı ile KDK'sinin azalması uçucu organik bileşikler ve asit fonksiyonel gruplardaki negatif yüzey yükü ile ilişkili olan parçalanma ile açıklanmaktadır (Singh ve ark., 2011; Uchimiya ve Hiradate, 2014). Bulgularımızın aksine, üretilen biyoçarların pH'larının yükselmesiyle birlikte, biyoçarların yüzeylerindeki negatif yüklü bölgeler artacağı, bunun da biyoçarın bazik katyonları elektrostatik çekim 
kuvveti ile tutmasını ve diğer iyonlarla değişebilirliğinin arttırmasını sağlayacă̆ı bildirilmiştir. Ayrıca, biyoçarların EC değerlerinin artmasının sulu çözeltilerdeki yarayıșlı iyonların konsantrasyonlarının artmasına neden olacağı ve bunun da üretilen biyoçarların değişim kapasitesini arttıracağı ifade edilmiştir (Chandra ve Bhattacharya, 2019).

Buğday samanı biyoçarında ise $300{ }^{\circ}{ }^{\circ}$ 'de 48.93 me $100 \mathrm{~g}^{-1}$ olarak belirlenen KDK değerinin $600{ }^{\circ} \mathrm{C}^{\prime}$ de 68.03 me 100 g $^{-1}$ 'e çıktığ görülmektedir (Çizelge 10). Büyükbaş hayvan gübresi, domates ve fasulye bitkilerinin atıkları ile kavak talaşından üretilen biyoçarlarda sıcaklık artışı ile KDK önemli miktarda azalma gösterirken, çeltik kavuzu ve mısır koçanından üretilen biyoçarların KDK değerlerindeki azalma \%4 civarında kalmıştır (Çizelge 6).

\section{Biyoçarların Besin Elementi Kapsamları}

\section{Biyoçarların Toplam Karbon ve Azot İçerikleri}

Topraktaki en önemli besin elementleri olan C ve N'un döngüsü biyoçarın piroliz sıcaklığından büyük ölçüde etkilenmektedir. Daha yüksek sıcaklıkta karbonlaşma oranının artması nedeni ile üretilen biyoçarların aromatikliğinin daha yüksek olması beklenmektedir (Novak ve ark., 2009). Bu tip biyoçarların doğada parçalanmadan çok uzun süre kalabilecek olması, sera gazı emisyonlarını dengelemek üzere topraklarda C zenginleşmesini sağlamak için önemli bir strateji olarak değerlendirilmektedir (Bruun ve ark., 2015). Sıcaklık artışı ile büyükbaş hayvan gübresinden üretilen biyoçarın toplam karbon içeriği azalırken fasulye biyoçarında bir değişim olmamış ancak diğer beş biyoçarın karbon içeriği artmıştır. Artışın en yüksek olduğu biyoçar çeşidi ise domates atıklarından elde edilen biyoçar çeşidi olmuştur.

Genel olarak, yüksek N içeriğine sahip olan biyoçarların toprağa önemli düzeyde besin elementi sağlayacağı ve ürün verimliliğini arttıracağı ifade edilmektedir. Sıcaklık artışı özellikle $400{ }^{\circ} \mathrm{C}$ 'den sonra toplam N içeriğinin önemli düzeyde azalmasına yol açmıştır. Üretilen biyoçarların çoğunluğunda sıcaklığın $300{ }^{\circ} \mathrm{C}$ 'den $400{ }^{\circ} C^{\prime}$ ye çıkarılması ile toplam $\mathrm{N}$ içeriğinin artışı söz konusu olmuştur (Çizelge 7). Özellikle çeltik kavuzu, fasulye atıkları, kavak talaşı, mısır koçanı ve buğday samanı biyoçarlarında bu artış çok belirgin olmuştur. Sert odun tipi hammaddelerin pirolizinden elde edilen biyoçar, yumuşak odun tipi bitkilerine kıyasla daha yüksek sıcaklıkta dahi yüksek $\mathrm{N}$ içeriğine sahip olma eğiliminde oldukları bildirilmiş (Al-Wabel ve ark., 2013) olmasına rağmen, kavak talaşı biyoçarından üretilen biyoçarın toplam $\mathrm{N}$ içeriği $600{ }^{\circ} \mathrm{C}^{\prime}$ deki piroliz sonrası çok büyük oranda azalmıştır. Chandra ve Bhattacharya (2019)'da piroliz sıcaklığının $400{ }^{\circ} \mathrm{C}$ 'den 700 ${ }^{\circ} \mathrm{C}$ 'ye yükseltilmesinde çeltik sapı biyoçarının azot içeriğinin \%64.95 oranında azaldığını bildirmişlerdir. Azot içeriğindeki azalma, düşük sıcaklıkta amin fonksiyonel grubunda ve yüksek sıcaklıkta ise piridin grubunda bulunan $\mathrm{NH}_{4}-\mathrm{N}, \mathrm{NO}_{3}-\mathrm{N}$ gibi uçucu özellikteki azot gruplarının kaybı ile ilişkilendirilmiştir (Khanmohammadi ve ark., 2015).

Çizelge 7. Farklı sıcaklıklarda üretilen biyoçarların toplam karbon ve azot içerikleri

\begin{tabular}{|c|c|c|c|c|c|c|c|c|}
\hline \multirow[t]{2}{*}{ Sicaklık ${ }^{\circ} \mathrm{C}$} & Büyükbaş & Çeltik & Domates & Fasulye & $\begin{array}{l}\text { Kavak } \\
\text { Talaşı }\end{array}$ & $\begin{array}{l}\text { Mısır } \\
\text { Koçanı }\end{array}$ & $\begin{array}{l}\text { Buğday } \\
\text { Samanı }\end{array}$ & $\begin{array}{l}\text { Genel } \\
\text { Ort. } \pm\end{array}$ \\
\hline & \multicolumn{8}{|c|}{ Toplam Karbon (\%) } \\
\hline 300 & 41.7 & 54.6 & 56.6 & 67.9 & 80.4 & 84.9 & 70.0 & $65.1 \mathrm{a}$ \\
\hline 400 & 39.4 & 54.1 & 56.2 & 68.0 & 88.6 & 89.5 & 71.7 & $66.8 \mathrm{a}$ \\
\hline 600 & 37.0 & 57.4 & 65.6 & 67.7 & 99.8 & 93.1 & 77.7 & $71.2 \mathrm{a}$ \\
\hline$\%$ Fark (300-600) & -11.1 & 5.2 & 15.9 & -0.4 & 24.1 & 9.6 & 10.9 & \\
\hline \multirow[t]{2}{*}{ ANOVA (P değeri) } & \multirow{2}{*}{\multicolumn{7}{|c|}{ Toplam Azot (\%) }} & \\
\hline & & & & & & & & \\
\hline 300 & 3 & 0.16 & 2.54 & 0.61 & 0.08 & 0.18 & 0.2 & $0.97 \mathrm{a}$ \\
\hline 400 & 2.82 & 2.92 & 3.01 & 4.24 & 5.8 & 4.25 & 1.74 & $3.54 \mathrm{~b}$ \\
\hline 600 & 0.28 & 0.41 & 0.32 & 0.41 & 0.11 & 0.24 & 2.43 & $0.60 \mathrm{a}$ \\
\hline \%Fark (300-600) & -90.7 & 156.3 & -87.4 & -32.8 & 37.5 & 33.3 & 1115.0 & \\
\hline \multirow[t]{2}{*}{ ANOVA (P değeri) } & $0.00^{* *}$ & & & & & & & \\
\hline & \multicolumn{7}{|c|}{ Karbon/Azot } & \\
\hline 300 & 13.9 & 340.9 & 22.3 & 111.3 & 1005.1 & 471.7 & 13.9 & $223.2 \mathrm{a}$ \\
\hline 400 & 14.0 & 18.5 & 18.7 & 16.0 & 15.3 & 21.1 & 14.0 & $287.1 \mathrm{a}$ \\
\hline 600 & 132.3 & 140.0 & 204.8 & 165.0 & 907.5 & 387.8 & 132.3 & $122.4 \mathrm{a}$ \\
\hline \%Fark (300-600) & 852.4 & -58.9 & 819.9 & 48.3 & -9.7 & -17.8 & 852.4 & \\
\hline ANOVA (P değeri) & $0.580 ̈ \mathrm{D}$ & & & & & & & \\
\hline
\end{tabular}

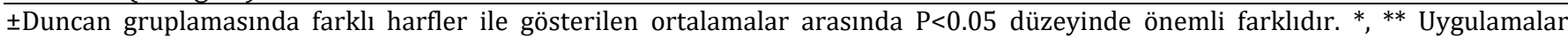
arasındaki fark sırası ile $\mathrm{P}<0.01$ ve $\mathrm{P}<0.05$ düzeyinde önemlidir, ÖD: Farklılık önemli değil. 
Sıcaklığın $400{ }^{\circ} C^{\prime}$ den $600{ }^{\circ}{ }^{\circ}$ 'ye çıkarılması ile birlikte tüm biyoçar çeşitlerinin toplam $\mathrm{C} /$ toplam N oranları önemli düzeyde artış göstermiștir. Kavak talaşı biyoçarının C/N oranı $400{ }^{\circ} C^{\prime}$ de 15.3 iken $600{ }^{\circ} C^{\prime}$ de 907.5 olmuş ve \%5834.4 oranında artmıștır. Biyoçar piroliz sıcaklığının değişimi toplam karbon ve karbon/azot oranı üzerine istatistiksel olarak önemli düzeyde etki etmez iken, toplam azot içeriği üzerine önemli düzeyde $\left(\mathrm{P}<0.01\right.$ ) etki yapmıştır (Çizelge 7). Ortalama toplam karbon içeriği $300 \mathrm{C}^{\prime}$ de $\% 65.1$ iken, $400{ }^{\circ} \mathrm{C}^{\prime} \mathrm{de} \% 66.8$ 'e ve $600{ }^{\circ} \mathrm{C}$ 'de ise \%71.2'ye yükselmiştir. Ortalama toplam azot içeriği ise, sıcaklığın $300{ }^{\circ} \mathrm{C}^{\prime}$ 'den $400{ }^{\circ} \mathrm{C}$ 'ye çıkarılması ile \%0.97'den \%3.54'e yükselmiş, ancak sıcaklığın 600 C’ye çıkarılması ile hızlıca kaybolarak \%0.60'a inmiştir (Çizelge 7).

\section{Biyoçarların Fosfor ve Potasyum İçerikleri}

Tüm biyoçar çeşitlerinde piroliz sıcaklığının $300{ }^{\circ} C^{\prime}$ den $600{ }^{\circ} C^{\prime}$ ye çıkarılması P içeriğinin artışına yol açmıştır. Sarfraz ve ark. (2019)'da daha yüksek sıcaklıklarda $\left(600{ }^{\circ} \mathrm{C}\right.$ ve $\left.700{ }^{\circ} \mathrm{C}\right)$ piroliz ile üretilen mantar atığı biyoçarının yüksek kül, $\mathrm{P}$ ve $\mathrm{K}$ içeriğine sahip olduğunu bildirilmiştir. Piroliz sıcaklığının artışı, potasyum içeriğinde fosfora kıyasla çok daha belirgin bir artışa neden olmuștur. $\mathrm{Bu}$ artış, fasulye atıklarından elde edilen biyoçarda \%111.7 düzeyinde olmuştur. Üretilen biyoçarların 300, 400 ve $600{ }^{\circ} C^{\prime} d e$ en yüksek potasyum içerikleri sırası ile $39.2,52.0$ ve $65.2 \mathrm{~g} \mathrm{~kg}^{-1}$ ile domates atıklarından elde edilen biyoçarlarda olmuştur (Çizelge 8). Makro besin elementi olan fosfor ve potasyum içerikleri, piroliz sıcaklığının değişiminden önemli düzeyde etkilenmemiştir. Biyoçarların ortalama fosfor ve potasyum içerikleri sıcaklık artışı ile istatistiksel olarak önemli olmamakla birlikte artmıştır (Çizelge 8).

Çizelge 8. Farklı sıcaklıklarda üretilen biyoçarların fosfor ve potasyum içerikleri

\begin{tabular}{|c|c|c|c|c|c|c|c|c|}
\hline \multirow[t]{2}{*}{ Sicaklık ${ }^{\circ} \mathrm{C}$} & Büyükbaş & Çeltik & Domates & Fasulye & $\begin{array}{l}\text { Kavak } \\
\text { Talașı } \\
\end{array}$ & $\begin{array}{l}\text { Misır } \\
\text { Koçanı } \\
\end{array}$ & $\begin{array}{l}\text { Buğday } \\
\text { Samanı }\end{array}$ & \multirow[t]{2}{*}{$\begin{array}{l}\text { Genel } \\
\text { Ort. } \pm\end{array}$} \\
\hline & \multicolumn{7}{|c|}{ Fosfor $\left(\mathrm{g} \mathrm{kg}^{-1}\right)$} & \\
\hline 300 & 19.0 & 4.3 & 8.4 & 7.3 & 3.2 & 4.9 & 4.3 & $7.3 a$ \\
\hline 400 & 21.9 & 4.2 & 10.2 & 8.1 & 3.7 & 5.4 & 4.4 & $8.3 \mathrm{a}$ \\
\hline 600 & 22.9 & 4.7 & 9.3 & 10.5 & 3.7 & 5.5 & 4.5 & $8.7 \mathrm{a}$ \\
\hline$\%$ Fark (300-600) & 20.8 & 10.7 & 11.4 & 43.7 & 15.3 & 11.0 & 5.1 & 19.1 \\
\hline \multirow[t]{2}{*}{ ANOVA (P değeri) } & $0.92 \mathrm{ÖD}$ & & & & & & & \\
\hline & \multicolumn{7}{|c|}{ Potasyum (g kg-1) } & \\
\hline 300 & 9.8 & 35.0 & 39.2 & 3.7 & 15.6 & 17.7 & 9.8 & $23.3 a$ \\
\hline 400 & 10.9 & 44.6 & 52.0 & 6.4 & 23.1 & 19.7 & 10.9 & $29.4 \mathrm{a}$ \\
\hline 600 & 12.7 & 45.5 & 65.2 & 7.9 & 27.3 & 25.8 & 12.7 & $34.2 \mathrm{a}$ \\
\hline$\%$ Fark (300-600) & 29.3 & 29.9 & 66.3 & 111.7 & 75.0 & 45.6 & 29.3 & 46.8 \\
\hline
\end{tabular}

£Duncan gruplamasında farklı harfler ile gösterilen ortalamalar arasında $\mathrm{P}<0.05$ düzeyinde önemli farklıdır. ÖD Uygulamalar arasındaki fark önemli değildir.

\section{Biyoçarların Kalsiyum ve Magnezyum İçerikleri}

Elde edilen veriler mısır koçanı ve buğday samanı biyoçarlarında Ca ve Mg konsantrasyonlarının artan piroliz sıcaklığı ile azaldığını; büyükbaş hayvan gübresi, domates atıkları ve kavak talaşından üretilen biyoçarda ise arttığını göstermiştir (Çizelge 9). Çeltik biyoçarında ise sıcaklık artışı ile Ca miktarı azalırken, Mg miktarının artışı söz konusu olmuştur. Mantar atıklarından hazırlanan biyoçarın Ca, Mg, Fe ve Zn gibi çok sayıda yarayışlı makro ve mikro besin elementi içeriğinin piroliz sıcaklığındaki artışla pozitif olarak korele olduğu rapor edilmiştir (Sarfraz ve ark., 2019). Bu durum, alkali elementlerin sıcaklık artışı ile biyoçardan uzaklaşmaması ve hammaddeki konsantrasyonları ile ilişkilendirilmiştir (Novak ve ark., 2009). Bu nedenle, alkalin elementlerin doygunluğu, yüksek sıcaklıklarda pirolize edilmiş biyoçarın kireçleme potansiyelinden sorumlu olduğu düşünülmektedir (Novak ve ark., 2009). Chandra ve Bhattacharya (2019)'da çeltik sapının piroliz sıcaklığının $400{ }^{\circ} C^{\prime}$ den $700{ }^{\circ} C^{\prime}$ ye çıkarılması ile değișebilir Ca ve Mg konsantrasyonlarının sırası ile \%5.04 ve \%23.29 oranında arttı̆̆ını bildirmişlerdir (Çizelge 9). Piroliz sıcaklığının değişimi biyoçarların alkali elementleri üzerine istatistiksel olarak önemli bir etki yapmamıştır. Ortalama Ca içeriği $300{ }^{\circ} C^{\prime}$ de 32.4 $\mathrm{g} \mathrm{kg}^{-1}$ iken 400 ve $600{ }^{\circ} \mathrm{C}^{\prime}$ lik piroliz sıcaklıklarında sırası ile 36.6 ve $38.3 \mathrm{~g} \mathrm{~kg}^{-1}$ 'a yükselmiştir. Ortalama $\mathrm{Mg}$ içeriği ise sırası ile 9.7, 11.2 ve $11.2 \mathrm{~g} \mathrm{~kg}^{-1}$ olarak tespit edilmiştir (Çizelge 9). 
Çizelge 9. Farklı sıcaklıklarda üretilen biyoçarların kalsiyum ve magnezyum içerikleri

\begin{tabular}{|c|c|c|c|c|c|c|c|c|}
\hline \multirow[t]{2}{*}{ Sicaklık $\stackrel{\circ}{-} \mathrm{C}$} & Büyükbaş & Çeltik & Domates & Fasulye & $\begin{array}{l}\text { Kavak } \\
\text { Talaşı }\end{array}$ & $\begin{array}{l}\text { Misır } \\
\text { Koçanı }\end{array}$ & $\begin{array}{l}\text { Buğday } \\
\text { Samanı }\end{array}$ & \multirow[t]{2}{*}{$\begin{array}{l}\text { Genel } \\
\text { Ort. } \pm\end{array}$} \\
\hline & \multicolumn{7}{|c|}{ Kalsiyum (g kg-1) } & \\
\hline 300 & 57.6 & 28.7 & 70.6 & 42.2 & 10.1 & 4.6 & 12.8 & $32.4 \mathrm{a}$ \\
\hline 400 & 65.0 & 18.1 & 88.5 & 49.6 & 16.3 & 3.8 & 14.7 & $36.6 \mathrm{a}$ \\
\hline 600 & 69.6 & 24.9 & 78.5 & 62.5 & 16.4 & 4.4 & 11.9 & $38.3 \mathrm{a}$ \\
\hline \%Fark (300-600) & 20.8 & -13.2 & 11.3 & 48.3 & 61.9 & -4.2 & -7.1 & \\
\hline \multirow[t]{2}{*}{ ANOVA (P değeri) } & $0.930 ̈ \mathrm{D}$ & & & & & & & \\
\hline & \multicolumn{7}{|c|}{ Magnezyum (g kg-1) } & \\
\hline 300 & 15.7 & 2.1 & 25.1 & 16.4 & 1.9 & 3.2 & 3.6 & $9.7 a$ \\
\hline 400 & 18.0 & 2.0 & 30.7 & 19.5 & 2.3 & 2.0 & 4.1 & $11.2 \mathrm{a}$ \\
\hline 600 & 19.2 & 2.4 & 24.8 & 24.0 & 2.5 & 2.1 & 3.3 & $11.2 \mathrm{a}$ \\
\hline \%Fark (300-600) & 22.2 & 12.8 & -1.3 & 46.5 & 35.0 & -34.2 & -8.6 & \\
\hline
\end{tabular}

£Duncan gruplamasında farklı harfler ile gösterilen ortalamalar arasında $\mathrm{P}<0.05$ düzeyinde önemli farklıdır. ÖD Uygulamalar arasındaki fark önemli değildir.

\section{Biyoçarların Kükürt ve Sodyum İçerikleri}

Büyük baş hayvan gübresi, çeltik kavuzu ve kavak talaşından üretilen biyoçarların kükürt (S) içeriği piroliz sıcaklığının $300 C^{\prime}$ 'den 600 C'ye artması ile sırası ile \%13.0, \%42.1 ve \%70.2 oranında azalmıştır. Bunun aksine domates atıkları, fasulye atıkları, mısır koçanı ve buğday samanından üretilen biyoçarların S içerikleri sıcaklık artışı ile sırası ile \%7.4, \%44.3, \%79.6 ve \%44.7 oranında artmıştır (Çizelge 10). Biyoçarların sodyum (Na) konsantrasyonları ise çeltik ve buğday samanında önemli düzeyde değişmez iken, diğer beş biyoçarda büyük oranda artmıştır. Özellikle mısır koçanından elde edilen biyoçarın Na içeriği 5184.9 oranında artmıştır (Çizelge 10).

Çizelge 10. Farklı sıcaklıklarda üretilen biyoçarların kükürt ve sodyum içerikleri

\begin{tabular}{|c|c|c|c|c|c|c|c|c|}
\hline \multirow[t]{2}{*}{ Sicaklık ${ }^{\circ} \mathrm{C}$} & Büyükbaş & Çeltik & Domates & Fasulye & $\begin{array}{l}\text { Kavak } \\
\text { Talașı }\end{array}$ & $\begin{array}{l}\text { Misır } \\
\text { Koçanı }\end{array}$ & $\begin{array}{l}\text { Buğday } \\
\text { Samanı }\end{array}$ & \multirow[t]{2}{*}{$\begin{array}{l}\text { Genel } \\
\text { Ort. }\end{array}$} \\
\hline & \multicolumn{7}{|c|}{ Kükürt (mg kg-1) } & \\
\hline 300 & 3714.0 & 510.6 & 6755.1 & 2199.4 & 980.5 & 516.5 & 1195.1 & $2267.3 a$ \\
\hline 400 & 3587.4 & 443.6 & 8629.8 & 2426.8 & 564.2 & 1673.3 & 1328.7 & $2664.8 \mathrm{a}$ \\
\hline 600 & 3232.3 & 295.8 & 7256.3 & 3174.7 & 292.3 & 927.4 & 1729.2 & $2415.4 a$ \\
\hline \%Fark (300-600) & -13.0 & -42.1 & 7.4 & 44.3 & -70.2 & 79.6 & 44.7 & \\
\hline \multirow[t]{2}{*}{ ANOVA (P değeri) } & 0.96ÖD & & & & & & & \\
\hline & \multicolumn{7}{|c|}{ Sodyum $\left(\mathrm{mg} \mathrm{kg}^{-1}\right)$} & \\
\hline 300 & 6521.9 & 2083.2 & 3051.7 & 2285.6 & 1630.1 & 2082.3 & 1976.4 & $2804.5 a$ \\
\hline 400 & 7234.1 & 2124.0 & 3240.2 & 2294.7 & 2045.6 & 3096.1 & 1894.0 & $3132.7 a$ \\
\hline 600 & 7986.0 & 2577.7 & 3181.7 & 2861.0 & 2041.4 & 5932.0 & 1892.8 & $3781.8 \mathrm{a}$ \\
\hline \%Fark (300-600) & 22.4 & 23.7 & 4.3 & 25.2 & 25.2 & 184.9 & -4.2 & \\
\hline ANOVA (P değeri) & $0.650 ̈ \mathrm{D}$ & & & & & & & \\
\hline
\end{tabular}

£Duncan gruplamasında farklı harfler ile gösterilen ortalamalar arasında $\mathrm{P}<0.05$ düzeyinde önemli farklıdır. ÖD Uygulamalar arasındaki fark önemli değildir.

Biyoçarların sodyum ve kükürt içerikleri piroliz sıcaklığının değişiminden önemli düzeyde etkilenmemiştir. Ortalama kükürt içeriği sıcaklığın 400 C'ye çıkarılması ile 2267.3 mg kg-1'dan 2664.8 mg kg-1'a yükselmiş, ancak sıcaklığın 600 C'ye çıkarılması ile 2415.4 mg kg-1'a düşmüştür (Çizelge 9). Kükürt içeriğinin aksine ortalama sodyum içeriği istatistiksel olarak önemli olmamakla birlikte sırası ile 2804.5, 3132.7 ve $3781.8 \mathrm{mg}$ $\mathrm{kg}^{-1}$ olarak ölçülmüştür.

\section{Biyoçarların Demir, Mangan, Bakır ve Çinko içerikleri}

Piroliz sıcaklığının artışı üretilen biyoçarların mikro besin elementi konsantrasyonlarının çoğunlukla artışına neden olmuştur. Bununla birlikte, özellikle Fe konsantrasyonu çeltik (\%8.9 azalma), mısır koçanı (\%23.7 azalma) ve buğday samanı (\%51.7 azalma) biyoçarları piroliz sıcaklığının $300{ }^{\circ} C^{\prime}$ den 600 o C'ye artışı ile azalmıştır (Çizelge 11). Sıcaklık artışı ile mikro besin elementlerinin konsantrasyonlarında önemli düzeyde farklılaşma olduğunu belirten Chandra ve Bhattacharya (2019), sicaklığın $400{ }^{\circ} C^{\prime}$ den $500{ }^{\circ} C^{\prime} y e$ çıkartılması ile $\mathrm{Ni}, \mathrm{Cu}$, Co ve $\mathrm{Cr}$ konsantrasyonlarının sırası ile \%21.7, 74.9, 67.0 ve 78.7 oranında arttığını belirtmişlerdir. Ancak, sıcaklığında 500'den 700 o C'ye çıkarılması ile belirtilen elementlerin konsantrasyonlarının sırası ile \%69.8, 93.4, 80.1 ve 88.0 oranında azaldığını rapor etmişlerdir. Benzer şekilde Fe ve Zn konsantrasyonlarının da $400{ }^{\circ} C^{\prime}$ 'den $700{ }^{\circ} C^{\prime}$ ye çıkarılması ile konsantrasyonlarının $\% 12.1$ 
ve \%83 oranında azaldığı tespit edilmiştir. Piroliz sıcaklığının artışı ile konsantrasyonu artan tek mikro besin elementinin ise Mn olduğu bildirilmiștir. Piroliz sıcaklığındaki değișim mikro besin elementlerinin hiçbirinde istatistiksel olarak önemli bir farklılaşmaya neden olmamıştır (Çizelge 11). Sıcaklık artışı ile mikro besin elementlerinin içerikleri istatistiksel olarak önemli olmamakla birlikte artmıştır.

Çizelge 11. Farklı sıcaklıklarda üretilen biyoçarların demir, mangan, bakır ve çinko içerikleri

\begin{tabular}{|c|c|c|c|c|c|c|c|c|}
\hline \multirow[t]{2}{*}{ Sicaklık ${ }^{\circ} \mathrm{C}$} & Büyükbaş & Çeltik & Domates & Fasulye & $\begin{array}{l}\text { Kavak } \\
\text { Talașı }\end{array}$ & $\begin{array}{l}\text { Misır } \\
\text { Koçanı }\end{array}$ & $\begin{array}{l}\text { Buğday } \\
\text { Samanı }\end{array}$ & \multirow[t]{2}{*}{$\begin{array}{l}\text { Genel } \\
\text { Ort. } \pm\end{array}$} \\
\hline & \multicolumn{7}{|c|}{$\operatorname{Demir}\left(\mathrm{mg} \mathrm{kg}^{-1}\right)$} & \\
\hline 300 & 14800.8 & 1664.9 & 2369.4 & 4268.3 & 1363.5 & 978.0 & 1332.3 & $3825.3 a$ \\
\hline 400 & 17081.2 & 1075.0 & 4464.8 & 5785.99 & 1039.7 & 1120.3 & 1369.1 & $4562.3 \mathrm{a}$ \\
\hline 600 & 18405.7 & 1516.7 & 4645.8 & 9247.37 & 658.9 & 990.0 & 1016.7 & $5211.6 \mathrm{a}$ \\
\hline \%Fark (300-600) & 24.4 & -8.9 & 96.1 & 116.7 & 1.2 & -23.7 & -51.7 & \\
\hline \multirow[t]{2}{*}{ ANOVA (P değeri) } & $0.910 ̈ \mathrm{D}$ & & & & & & & \\
\hline & \multicolumn{7}{|c|}{ Mangan (mg kg-1) } & \\
\hline 300 & 563.4 & 290.4 & 159.1 & 201.7 & 34.4 & 51.8 & 128.4 & $204.2 \mathrm{a}$ \\
\hline 400 & 649.9 & 309.0 & 231.8 & 263.1 & 34.2 & 47.9 & 141.1 & $239.6 a$ \\
\hline 600 & 683.2 & 361.7 & 227.7 & 350.2 & 31.3 & 46.5 & 129.8 & $261.5 \mathrm{a}$ \\
\hline \%Fark (300-600) & 21.3 & 24.6 & 43.2 & 73.6 & -10.2 & 1.1 & -9.2 & \\
\hline \multirow[t]{2}{*}{ ANOVA (P değeri) } & $0.87 \mathrm{ÖD}$ & & & & & & & \\
\hline & \multicolumn{7}{|c|}{ Bakır (mg kg-1) } & \\
\hline 300 & 58.4 & 9.4 & 1150.5 & 76.2 & 35.8 & 12.9 & 9.6 & 193.3a \\
\hline 400 & 59.5 & 5.8 & 1505.1 & 88.2 & 41.3 & 32.7 & 41.0 & $253.4 \mathrm{a}$ \\
\hline 600 & 70.4 & 8.7 & 1435.0 & 105.3 & 60.4 & 15.0 & 31.5 & $246.6 a$ \\
\hline \%Fark (300-600) & 20.4 & -7.6 & 24.7 & 38.2 & 68.7 & 16.0 & 229.5 & \\
\hline \multirow[t]{2}{*}{ ANOVA (P değeri) } & $0.97 \mathrm{ÖD}$ & & & & & & & \\
\hline & \multicolumn{7}{|c|}{ Çinko (mg kg-1) } & \\
\hline 300 & 182.3 & 34.0 & 173.6 & 51.8 & 51.8 & 70.8 & 32.8 & $91.0 \mathrm{a}$ \\
\hline 400 & 217.5 & 33.1 & 202.1 & 66.3 & 91.4 & 91.8 & 68.9 & $114.2 \mathrm{a}$ \\
\hline 600 & 216.5 & 41.3 & 195.4 & 92.0 & 119.8 & 100.3 & 38.9 & $115.0 \mathrm{a}$ \\
\hline \%Fark (300-600) & 18.8 & 21.3 & 12.6 & 77.7 & 120.2 & 41.6 & 18.6 & \\
\hline ANOVA (P değeri) & $0.760 ̈ \mathrm{D}$ & & & & & & & \\
\hline
\end{tabular}

\section{Sonuç}

$\mathrm{Bu}$ çalışma, pirolizin sıcaklığının yedi farklı hammaddeden üretilen biyoçarların verimi ve bir kısım fiziksel ve kimyasal özellikleri üzerindeki etkilerini araştırmak amacı ile yürütülmüştür Sonuçlar, biyoçarların çalışılan tüm özellikleri üzerine piroliz sıcaklığının önemli etkisi olduğunu, ancak etkinin boyutunun biyoçar üretiminde kullanılan hammaddenin özelliklerine bağlı olarak değiştiğini göstermiștir. Bu çalışmada üretilen biyoçarın $\mathrm{pH}$ değerlerinin yüksek olması, toprakta $\mathrm{Fe}, \mathrm{Zn}$, $\mathrm{Mn}$ ve $\mathrm{Cu}$ gibi mikro besin elementlerinin yarayışlılığını azaltabilecek bir özellik olarak öne çıkmaktadır. Ancak bu durum toprağın KDK'sini artırabilecek alkali kimyasal türlerin varlığını da göstermektedir. Alkali kimyasal türlerin varlığı, toprakta P'un çökelmesini ve adsorpsiyonunu azaltabilecek ve ayrıca Ca ve $\mathrm{K}$ gibi besin elementlerinin bitkilere yarayışlılığını arttırabilecektir. Hayvan gübresinden üretilen biyoçar ilave edilen toprakta P yarayışlılığı, hayvan gübresinin ilave edildiği toprağa kıyasla başlangıçta daha düşük olacaktır. Ancak hayvan gübresi ilave edilmiş toprakta yarayışlılık kademeli olarak azalacağından, uzun süreli denemelerde hayvan gübresi biyoçarı ilave edilmiş toprakta P'un yarayışlılığının zamanla arttığı bildirilmiştir. Bu nedenle, uygulama sonrası hemen fosfora ihtiyaç duyan ürünler için nispeten daha düşük piroliz sıcaklıklarında üretilen ve daha yüksek konsantrasyonda fosfor içeren biyoçarlar kullanılmalıdır.

Tüm biyoçar çeşitlerinde artan sıcaklıkla birlikte TC içeriğinin önemli düzeyde artışı söz konusudur. Bu durum, üretilen biyoçarın ayrışmaya karşı daha dayanıklı bir hal almasına neden olurken, $\mathrm{C} / \mathrm{N}$ oranının artması nedeni ile azotun yarayışlılığının azalmasına da yol açacaktır. Yüksek $\mathrm{C} / \mathrm{N}$ oranına sahip materyallerin toprağa uygulanması, belirli bir dönem bitkilerin N noksanlığı yaşamalarına neden olabilir. Bu nedenle, ilave N kullanımı gerekebilir. Sıcaklık artışı ile SYA'ları azalsa da üretilen biyoçarların SYA değerleri şişme büzülme potansiyeli yüksek olan smektit grubu kil minerallerine yakındır. SYA değerlerinin yüksek olması, bu yüzeylerde daha fazla su ve besin elementi tutumunun olabileceğine işaret etmektedir. Bu durum, o yüzeylerde daha fazla mikroorganizmanın barınabileceğini ve beslenebileceğini de anlatmaktadır. Özellikle 
kum içeriği yüksek olan toprakların yüzey alanlarında bir artışa neden olması, biyoçarın topraktaki biyoçeşitliliğe de olumlu katkı yapması anlamına gelecektir.

Biyoçar içerisinde besin elementlerinin bir kısmı sıcaklık artarken azalırken, diğer bir kısmı (K gibi) sıcaklık artışı ile birlikte daha yoğun hale gelmiştir. Daha düşük sıcaklıklarda buharlaşarak uzaklaştığı bilenen N ve $S$ gibi besin elementlerinin uzaklaşması, yüksek sıcaklıklarda üretilen biyoçarların gübre görevi görmesini engelleyecek bir durumdur. Bu durumda, yüksek sıcaklıkta üretilen biyoçarlar, gübre olmaktan çok toprağın fiziksel özelliklerini düzeltecek birer katkı maddesi olarak düşünülmeleri gerekir. Toprağın fiziksel özelliklerinin düzelmesi de gübre etkisi gibi bitki gelişimini olumlu etkileyecek, dahası toprağın kalitesinin ve bitkisel üretimin sürdürülebilirliğinin gelişmesini de sağlayacaktır.

\section{Kaynaklar}

Ahmad M, Lee SS, Dou X, Mohan D, Sung J-K, Yang JE, 2012. Effects of pyrolysis temperature on soybean stover- and peanut shell-derived biochar properties and TCE adsorption in water. Biores. Techn., 118:536-44.

Al-Wabel MI, Al-Omran A, El-Naggar AH, Nadeem M, Usman AR, 2013. Pyrolysis temperature induced changes in characteristics and chemical composition of biochar produced from conocarpus wastes. Biores. Technology, 131:374-379.

Angin, D, 2013. Effect of pyrolysis temperature and heating rate on biochar obtained from pyrolysis of safflower seed press cake. Biores. Tech., 128: 593-597.

Banik C, Lawrinenko M, Bakshi S, Laird DA, 2018. Impact of pyrolysis temperature and feedstock on surface charge and functional group chemistry of biochars. J. Envir. Qual., 47:452-461.

Bayram Ö, 2016. Farklı tarımsal atıklardan üretilen biyocharların çeşitli fiziksel ve kimyasal özelliklerinin belirlenmesi. Gaziosmanpaşa Üniversitesi, Fen Bilimleri Enstitüsü. Yüksek Lisans Tezi. YÖK Tez No: 420461.

Brady NC, Weil RR, 1999. The nature and properties of soil $12^{\text {th }}$ ed. Mac. Pub. Com. New York.

Bruun TB, Elberling B, Neergaard AD, Magid J, 2015. Organic carbon dynamics in different soil types after conversion of forest to agriculture. Land Degrad. Dev. 26:272-283.

Chandra S, Bhattacharya J, 2019. Influence of temperature and duration of pyrolysis on the property heterogeneity of rice straw biochar and optimization of pyrolysis conditions for its application in soils. J. Cleaner Prod., 215:11231139.

Chen FS, Yavitt J, Hu XF, 2014. Phosphorus enrichment helps increase soil carbon mineralization in vegetation along an urban-to-rural gradient, Nanchang, China. Appl. Soil Ecol., 75:181-188.

Cerato A, Lutenegger A, 2002. Determination of surface area of fine-grained soils by the ethylene glycol monoethyl ether (EGME) method. Geotech. Test. J. 25(3):1-7.

Das O, Sarmah AK, 2015. The love-hate relationship of pyrolysis biochar and water: a perspective. Sci Total Environ., 682(5):512-513.

Gray M, Johnson MG, Dragila MI, Kleber M, 2014. Water uptake in biochars: the roles of porosity and hydrophobicity. Biomass Bioenergy, 61:196-205.

Günal E, 2018. Sıvı Hayvan Gübresi ile Zenginleştirilmiş Biyoçarların Ekmeklik Buğdayın Gelişimi, Besin Elementi Alımı ve Toprak Kalitesine Etkileri. Tokat Gaziosmanpaşa Üniversitesi, Fen Bilimleri Enstitüsü, Doktora Tezi. s. 345. YÖK Tez No: 516795.

Joseph SD, Camps-Arbestain M, Lin Y, Munroe P, Chia CH, Hook J, Van Zwieten L, Kimber S, Cowie A, Singh BP, ve ark. 2010. An investigation into the reactions of biochar in soil. Soil Research. 48:501-515.

Inyang M, Dickenson E, 2015. The potential role of biochar in the removal of organic and microbial contaminants from potable and reuse water: A review. Chemosphere, 34: 232-240.

Ippolito J, Spokas K, Novak J, Lentz R, Cantrell K, 2015. Biochar elemental composition and factors influencing nutrient retention. In: Lehman J, Joseph S, editors. Biochar Environ Management, New York-

Kacar B, İnal A, 2008. Bitki Analizleri. Nobel Yayın No:1241, 892 s.

Kammann CI, Linsel S, Gößling JW, Koyro HW, 2011. Influence of biochar on drought tolerance of Chenopodium quinoa Willd and on soil-plant relations. Plant Soil 345:195-210.

Khanmohammadi Z, Afyuni M, Mosaddeghi M.R, 2015. Effect of pyrolysis temperature on chemical and physical properties of sewage sludge biochar. Waste Manag. Res. 33(3):275-283.

Kloss S, Zehetner F, Dellantonio A, Hamid R, Ottner F, Liedtke V, Schwanninger M, Gerzabek MH, Soja G, 2012. Characterization of Slow Pyrolysis Biochars: Effects of Feedstocks and Pyrolysis Temperature on Biochar Properties. J. Environ. Qual., 41:90-1000.

Klute A, 1986. Water Retention: Laboratory Methods. Methods of Soil Analysis. Part1. 2nd Ed. Agronomy 9. Am. Soc. Agron., 635-660, Madison.

Lee Y, Park J, Ryu C, Gang KS, Yang W, Park YK, Hyun S, 2013. Comparison of biyoçar properties from biomass residues produced by slow pyrolysis at 500 C. Bioresour. Tech., 148:196-201.

Lehmann J, Joseph S, 2009. Biyoçar for Environmental Management: An Introduction. Lehmann, J., Joseph, S. (Eds.). Biyoçar for environmental management: science and technology. Earthscan. pp. 1-12.

Li HB, Dong XL, Evandro BS, Letuzia MO, Chen YS, Lena QM, 2017. Mechanisms of metal sorption by biochars: biochar characteristics and modifications. Chemosphere 178:466-478. 
Mahawar N, Goyal P, Lakhiwal S, Jain S, 2015. Agro Waste: A New Eco- Friendly Energy Resource. Int. Res. J. Environ. Sci. 4:47-49.

McLean EO, 1982. Soil pH and lime requirement. Methods of soil analysis. Part 2. Chemical and microbiological properties, pp. 199-224.

Mukherjee A, Zimmerman AR. Harris W, 2011. Surface chemistry variations among a series of laboratory-produced biochars. Geoderma, 163(3-4):247-255.

Novak J, Lima I, Xing B, Gaskin JW, Steiner C, Das KC, Ahmedna M, Rehrah D, Watts DW, Busscher WJ, 2009. Characterization of designer biochar produced at different temperatures and their effects on a loamy sand. Ann. Environ. Sci., 3:195-206.

Pereira RC, Kaal J, Arbestain MC, Lorenz RP, Aitkenhead W, Hedley M, Macíasc F, Hindmarshd Maciá-Agullóe JA, 2011. Contribution to characterization of biochar to estimate the labile fraction of carbon. Org. Geochem. 42(11):13311342

Sarfraz R, Shakoor A, Abdullah M, Arooj A, Hussain A, Xing S, 2017. Impact of integrated application of biochar and nitrogen fertilizers on maize growth and nitrogen recovery in alkaline calcareous Soil. J. Soil Sci. Plant Nutr., 63:488-498.

Sarfraz R, Li S, Yang W, Zhou B, Xing S, 2019. Assessment of physicochemical and nutritional characteristics of waste mushroom substrate biochar under various pyrolysis temperatures and times. Sustainability, 11(1), 277.

Singh BP, Joseph S, 2011. The mean residence time of biochar-mineral complexes in soil. In Proceedings of the Asia Pacific Biochar Conference 2011, Kyoto, Japan, 15-18 September 2011; Volume 2119.

Sizmur T, Quilliam R, Puga AP, Moreno-Jiménez E, Beesley L, Gomez-Eyles JL, 2015. Application of Biyoçar for Soil Remediation. Agricultural and Environmental Applications of Biyoçar: Advances and Barriers, (sssaspecpub63)

Sohi SP, 2012. Carbon storage with benefits. Science 338:1034-1035.

Sumner ME, Miller WP, 1996. Cation exchange capacity, and exchange coefficients. In: D.L. Sparks (ed.) Methods of soil analysis. Part 2: Chemical properties (3rd ed.). ASA, SSSA, CSSA, Madison, WI.

Sun J, He F, Pan Y, Zhang Z, 2017. Effects of pyrolysis temperature and residence time on physicochemical properties of different biochar types. Acta Agric. Scand. Sect. B Soil Plant Sci. 67:12-22.

Tabatabai MA, 1994. Soil enzymes. Pages 775-833 in R.W. Weaver, S. Angle, P.Bottomley, D. Bezdicek, S. Smith, A. Tabatabai, and A. Wollum, editors. Methods of soil analysis. Part 2. Microbiological and biochemical properties. Soil Sci. Society of America, Segoe, Wisconsin, USA.

Tarpeh WA, Udert KM, Nelson KL, 2017. Comparing ion exchange adsorbents for nitrogen recovery from SourceSeparated urine. Env. Sci. Technol. 51:2373-2381.

Uchimiya M, Hiradate S, 2014. Pyrolysis temperature-dependent changes in dissolved phosphorus speciation of plant and manure biochars. J. Agric. Food Chem., 62:1802-1809.

Xu D, Cao J, Li Y, Howard A, Yu K, 2019. Effect of pyrolysis temperature on characteristics of biochars derived from different feedstocks: A case study on ammonium adsorption capacity. Waste Manage., 87:652-660.

Yin QQ, Wang RK, Zhao ZH, 2018. Application of Mg-Al-modified biochar for simultaneous removal of ammonium, nitrate, and phosphate from eutrophic water. J. Clean Prod. 176:230-240.

Yuan JH, Xu RK, Zhang H, 2011. The forms of alkalis in the biochar produced from crop residues at different temperatures. Bioresour. Technol. 102:3488-3497.

Weber K, Quicker P, 2018. Properties of biochar. Fuel 217:240-261.

Woolf D, Amonette JE, Street-Perrott FA, Lehmann J, Joseph S, 2010. Sustainable biyoçar to mitigate global climate change. Nat. Commun. 1. Article Number 56.

Wu W, Yang M, Feng Q, McGrouther K, Wang H, Lu H, Chen Y, 2012. Chemical characterization of rice straw-derived biochar for soil amendment. Biomass Bioenergy 47:268-276.

Zhang H, Chen C, Gray EM, Boyd SE, Yang H, Zhang D, 2016. Roles of biochar in improving phosphorus availability in soils: A phosphate adsorbent and a source of available phosphorus. Geoderma, 276:1-6.

Zhang H, Chen C, Gray EM, Boyd SE, 2017. Effect of feedstock and pyrolysis temperature on properties of biochar governing end use efficacy. Biomass and Bioenergy, 105, 136-146. 